\title{
Synthesis and Characterization Glycidyl Azide Polymer of an Attractive Binder for Energetic Materials
}

\author{
Jovica Nešicí ${ }^{1)}$ \\ Aleksandar Marinković ${ }^{2)}$ \\ Zoran Bajic ${ }^{3)}$ \\ Saša Brzić ${ }^{1)}$
}

\begin{abstract}
The glycidyl azide polymer (GAP), known as an energetic, thermally stable, low sensitive, hydroxyl-terminated prepolymer, was synthesized using different diol and triol initiator units. GAP was prepared by azidation of poly(epichlorohydrin) (PECH) with different polyol units in the polymer chain. PECH was obtained by cationic ring-opening polymerization of epichlorohydrin, with $\mathrm{BF}_{3}$-etherate as a catalyst and polyol as a co-catalyst. The synthesized polymers have been characterized using IR-spectroscopy, while the prepolymers structure was confirmed by proton NMR spectroscopy. Additionally, glass transition temperature (Tg) and sensitivity to thermal stimuli were determined. Physico-chemical and rheological performances were carried out towards: end groups analysis, as well as density and molecular mass determination
\end{abstract}

Key words: polymers, polymer binder, glycidyl azide polymer, energetic polymers, chemical synthesis, material properties, physico-chemical performances.

\section{Nomenclature}

HTPB - hydroxyl-terminated poly(butadiene)

$\mathrm{NC}$ - nitrocellulose

GAP - glycidyl azide polymer

PECH - poli(epichlorhydrine)

ECH - epichlorhydrine

BD -1,4-butanediol

ED - ethane-1,2-diol

GLY - glycerol

BTFE - boron trifluoride etherate

$T_{\mathrm{g}} \quad-$ glass transition temperature

CAUTION! All azido containing compounds are potentially explosive energetic materials. Although no hazards were observed during the preparation and handling of these compounds, nevertheless, their synthesis and handling requires additional meticulous safety precautions (grounded equipment, Kevlar ${ }^{\circledR}$ gloves, Kevlar ${ }^{\circledR}$ sleeves, face shield, leather coat, and ear plugs).

\section{Introduction}

$\mathrm{B}$ INDERS are important components of most commonlyused solid-phase military explosives, smokeless powder, rocket propellants, pyrotechnics and gun propellants, improving both structural integrity and moisture resistance. Inert polymeric binders assume many different forms, from simple natural waxes, to more complex polymeric materials such as chemically cross-linked urethane and epoxy-cured binders based on synthetic polymers such as HTPB (hydroxyl-terminated polybutadiene). The use of inert polymers has been widely reported [1-8]. Although these polymers are well suited as binders due to their properties, they have a major issue of being non-energetic [9]. Energetic binders are polymers containing energetic functional groups (explosophores) along their polymer backbone which provide additional energy to the energy balance of the system. Such energetic groups are azido $\left(-\mathrm{N}_{3}\right)$, nitro $\left(-\mathrm{NO}_{2}\right)$, nitrate ester $(-$ $\left.\mathrm{O}-\mathrm{NO}_{2}\right)$ and nitramino $\left(-\mathrm{N}-\mathrm{NO}_{2}\right)[10]$. NC (Nitrocellulose), a polymeric nitrate ester was the first polymer used in energetic formulations [11].

Organic azides are a unique class of novel energetic compounds with azido group. The azido groups improve the energy levels and endue excellent performance of high energetic materials [12-15]. The azido functionalized polymers such as glycidyl azide polymer (GAP), were reported as the next generation of energetic binders in the early 1980s (Fig.1) [16]. This polymeric azide is used as an energetic binder (produced at range of average molecular weight, $M_{n}$, from 2.000 to 10.000 ), and as a plasticizer (at $M_{n}$ of about 500) in composite energetic systems to impart additional energy to the formulations which increase the performance and enhance the stability and the mechanical properties of the system.<smiles>COC(C)CC(C)O</smiles>

Figure 1. Glycidyl azide polymer (GAP)

GAP was firstly synthesized in 1972 by the reaction of sodium azide with poly(epichlorohydrin) in dimethylformamide [17]. This general method was

\footnotetext{
1) Military Technical Institute (VTI), Ratka Resanovića 1, 11132 Belgrade, SERBIA

2) University of Belgrade, Faculty of Technology and Metallurgy, Karnegijeva 4, 11020 Belgrade, SERBIA

3) University of Defence, Military Academy, Generala Pavla Jurišića Šturma 33,11000 Belgrade, SERBIA

Correspondence to: Jovica Nešić; e-mail: jovicanesic@yahoo.com
} 
subsequently used for synthesis of either linear or branched GAP prepolymers starting from different PECH precursor. Optimization of PECH synthesis has led to the successful development of a process which yields GAP prepolymers with average molecular weights of from 2100 to 4000, terminal functionalities (the number of reactive hydroxyl groups per molecule) from 1.6 to 3.1 , which depends on the catalyst and initiator used, as well as the ratio of $\mathrm{ECH} /$ initiator. Using different aliphatic diol, e.g. ethandiol or butanediol, difunctional linear $\mathrm{PECH}$ product could be obtained. In the other hand, PECH triol (Fig.2) was synthesized by polymerization of epichlorohydrin (ECH) with glycerol as the initiator unit. The azidation step can be now carried out in aqueous solvent or organic solvent or in polyethylene oxide. In order to achieve the desired level of crosslinking to produce a tough and elastomeric rubber, it must be raised by the addition of triols or using with triisocyanate cross linkers [18].

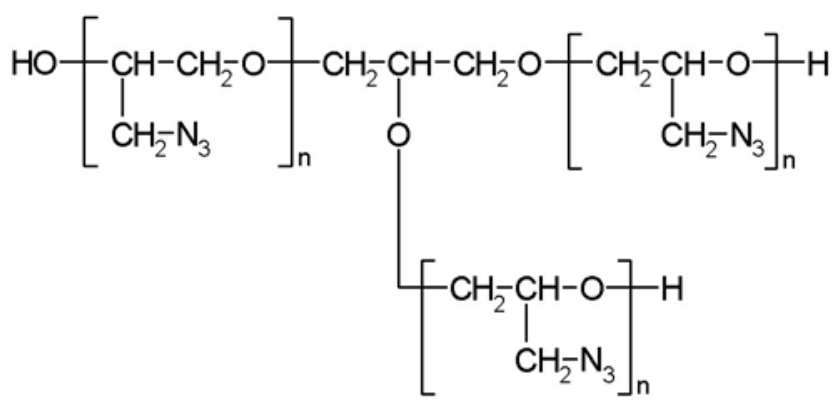

Figure 2. GAP triol

The energetic properties of GAP are not a consequence of its oxidation products, but rather are due to the chain scission of the azide group, which gives nitrogen gas with a heat of reaction of $+957 \mathrm{~kJ} / \mathrm{kg}$ at $5 \mathrm{MPa}$. GAP also contains a relatively high concentration of carbon atoms, and therefore has a high combustion potential, burning smoothly at elevated temperatures and pressure $(>0.3 \mathrm{MPa})$ without explosion [16].

The aim of this work was related to synthesis of PECH precursors and GAP energetic polymer for binder application containing various initiative polyol units in the polymer chain at various molar ratios. Effects of initiator and solvent polarity of yields and molecular weight $(M n)$, determined by using ${ }^{1} \mathrm{H}$ NMR and viscosimetry, were considered as well. Glass transition temperature $(T \mathrm{~g})$ and practical determination of sensitivity to thermal stimuli were determined as an important criterion which defines usefulness of energetic binder.

\section{Experimental part}

\section{Materials}

All chemical reagents and solvents of analytical grade were obtained from Sigma Aldrich, Acros Organic, Fluka, Merck or ABCR and used without further purification. Epichlorohydrin (ECH), dicloromethane (DCM), butane-1,4diol (BD), glycerol (GLY), boron trifluoride etherate (BTFE) catalyst, ethane-1,2-diol (ED), sodium sulphate, sodium azide, sodium chloride, Tinn(IV) chloride $\left(\mathrm{SnCl}_{4}\right), \quad N, N$ dimethylformamide (DMF), $N, N$-dimethylacetamide (DMA), dimethylsulfoxide (DMSO), deuterated chloroform $\left(\mathrm{CDCl}_{3}\right)$ are commercially available materials.

\section{Synthesis of GAP}

GAP polymer was synthesized in two steps (Figure 3). First step was the synthesis of poly(epichlorohydrin) of appropriate molecular weight. Second step included conversion of PECH polymer to GAP.

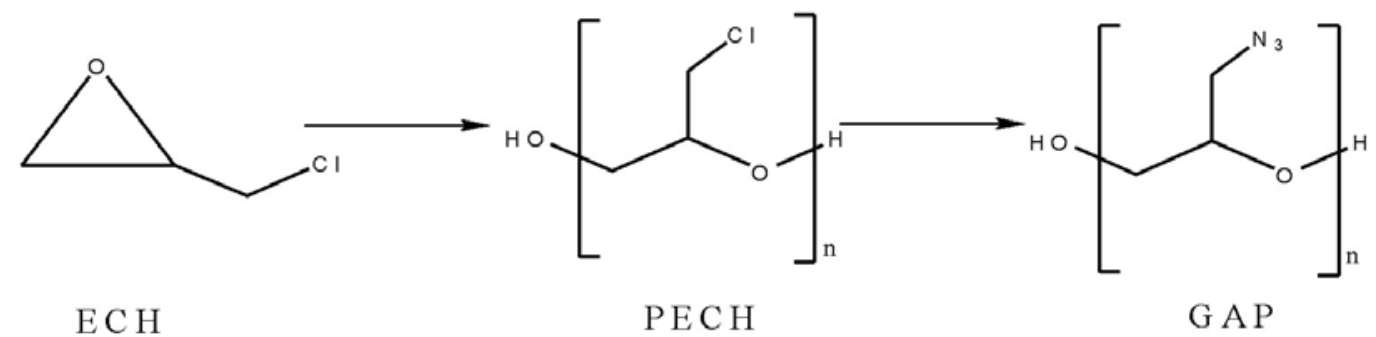

Figure 3. Two steps of GAP synthesis

\section{Synthesis of poly(epichlorohydrin)}

The ring-opening polymerization of ECH was performed in a $250 \mathrm{ml}$ four-neck reactor equipped with mechanical stirrer, condenser with calcium chloride tube, thermometer and nitrogen inlet. Firstly, the initiator for polymerization reactor and solvent DCM were placed into reactor afterwards boron trifluoride etherate catalyst was added dropwise for $5 \mathrm{~min}$ followed by vigorous stirring for $10-20 \mathrm{~min}$ at the room temperature. Three different types of initiators were used: ED, GLY and BD where their influence on the conversion degree of ECH was traced out. Then ice-salt bath was used to bring the reaction to $0^{\circ} \mathrm{C}$ and when reactor content reached targeted temperature the monomer $\mathrm{ECH}$ was added dropwise to the initiator/catalyst mixture over a period of 20-30 min. Further on, the polymerization reaction was carried out in the following $48 \mathrm{~h}$, the obtained product polyepichlorohydrin (PECH) was dissolved in $25 \mathrm{ml}$ of DCM and washed with distilled water. Non-reacted compounds were removed from polymer solution layer by washing with distilled water for several times, and finally the same layer was dried over sodium sulphate. The pure polymer was obtained by removing solvent after vacuum distillation [19-22].

\section{Preparation of glycidyl azide polymer}

The PECH solution was introduced into a three-neck flask equipped with a condenser, a magnetic needle, and a calcium chloride guard tube. The reaction mixture was heated slowly until the polymer was dissolved in the solvent. To this reaction mixture, sodium azide (in equimolar ratio) was added slowly and temperature was raised to $110^{\circ} \mathrm{C}$. After $8-12 \mathrm{~h}$ of reaction time solution the reactor content was cooled to the room temperature. Afterwards the obtained product was filtered to remove non-reacted sodium azide and sodium chloride (by product), and then washed several times with distilled water [19-22]. GAP triol was prepared by following the procedure, given in Fig.4.

The polymerization is followed by the azidation reaction in aprotic polar solvents which gives the product in $87-96 \%$ yield. The solvents used for the azidation are dimethylsulfoxide (DMSO), dimethylformamide (DMF) or dimethylacetamide (DMA). 
${ }_{\mathrm{O}}^{\mathrm{H}} \stackrel{\mathrm{Cl}}{\mathrm{CH}-\mathrm{CH}_{2}}$

$\mathrm{ECH}$
$+$<smiles>OCC(O)CO</smiles>

Glycerol

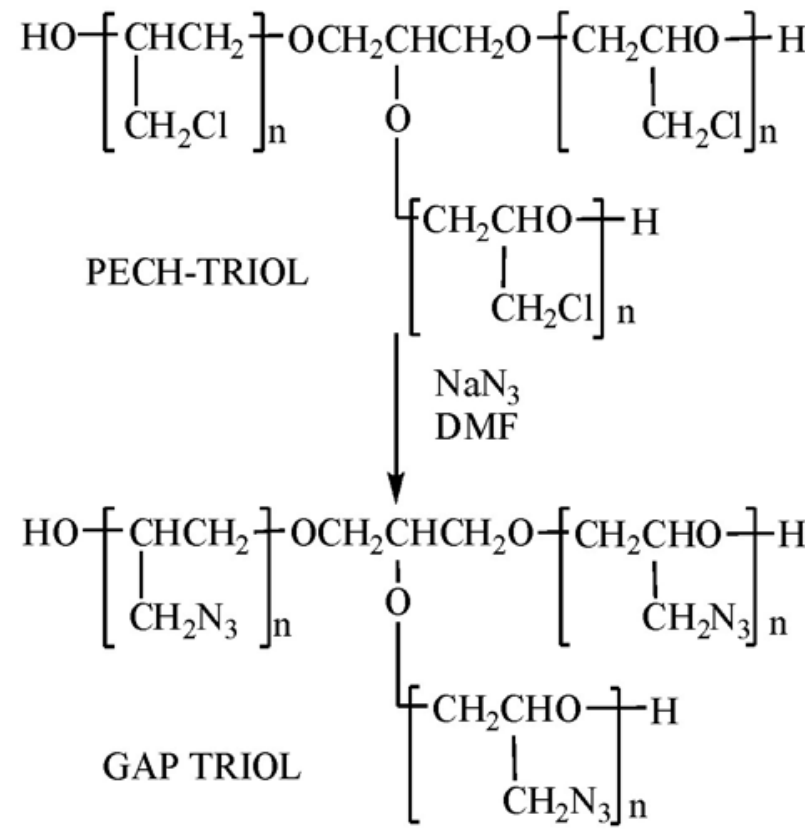

Figure 4. Synthesis of GAP triol

\section{Characterization methods}

Fourier transforms infrared spectroscopy (FTIR) spectra of the synthesized PECH and GAP polymer were recorded in absorbance mode using a Nicolet $^{\mathrm{TM}}$ iS ${ }^{\mathrm{TM}} 10$ FT-IR Spectrometer (Thermo Fisher SCIENTIFIC) with Smart iTR ${ }^{\mathrm{TM}}$ Attenuated Total Reflectance (ATR) sampling accessories, within a range of $400-4000 \mathrm{~cm}^{-1}$, at a resolution of $4 \mathrm{~cm}^{-1}$ and in 20 scan mode. All spectra were recorded at ambient temperature; all samples were neat liquids. ${ }^{1} \mathrm{H}$ nuclear magnetic resonance (NMR) spectra of synthesized polymer were recorded in deuterated chloroform $\left(\mathrm{CDCl}_{3}\right)$, using a Bruker Avance III 400 spectrometer at $200 \mathrm{MHz}$. The Chemicals shifts are expressed in ppm value referenced to trimethylsilane (TMS) as a standard in the ${ }^{1} \mathrm{H}$ NMR spectra. The glass transition temperature was determined using differential scanning calorimetry (DSC). The analysis was performed with DSC Q20 manufactured by TA Instruments with liquid nitrogen cooling for low temperatures. The measurements were performed under a nitrogen flow of $50 \mathrm{ml} \mathrm{min}{ }^{-1}$ in the temperature range from $-90^{\circ} \mathrm{C}$ to $20^{\circ} \mathrm{C}$, using a heating rate of $5 \mathrm{~K} / \mathrm{min}^{-1}$.

The viscosity measurements of GAP were carried out at $25^{\circ} \mathrm{C}$ using a modified Ubbelohde viscometer. The viscometer bath was controlled with in $\pm 0.02^{\circ} \mathrm{C}$ and the flow times of solutions were measured using an automatic timer. The flowtime data were first used for the calculations of the relative viscosity, $\eta_{r}$, and the specific viscosity, $\eta_{\mathrm{sp}}$, of the solutions. The intrinsic viscosity, $[\eta]$, was then obtained by a linear regression of both $\left(\ln \eta_{\mathrm{r}}\right) / \mathrm{c}$ and $\left(\eta_{\mathrm{sp}} / \mathrm{c}\right)$ versus $c$, where $c$ is the concentration of solutions varying from about $1.700 \times 10^{-2} \mathrm{~g}$ $\mathrm{cm}^{-3}$ to $0.400 \times 10^{-2} \mathrm{~g} \mathrm{~cm}^{-3}$. The correlation coefficients were higher than 0.975 .

The hydroxyl value of the polymer was estimated by treating $2 \mathrm{~g}$ of standard acetylating agent $(66 \mathrm{ml}$ pyridine / 33 $\mathrm{ml}$ acetic anhydride) for $15 \mathrm{~min}$ at $95^{\circ} \mathrm{C}$. Each analysis was compared with a blank by titrating with $0.1 \mathrm{~N}$ methanolic potassium hydroxide. The difference in titrant between sample and blank was used to calculate the hydroxyl value of the polymer. The hydroxyl value of each polymer was determined from three measurements, and average value was calculated.

The end groups (OH groups) have been analyzed via classical titration method following the procedure described in the SORS 1472/83 standard.

Ignition temperature was determined with "Julius Peters" apparatus. Sample size was $0,2 \mathrm{~g}$ (in a boron-silicate glass tube), using a heating rate of $5^{\circ} \mathrm{C} / \mathrm{min}$ with start temperature was $100^{\circ} \mathrm{C}$ (for ignition temperature). Molecular weight measurements of GAP were determined by viscosimetry and ${ }^{1} \mathrm{H}$ NMR analysis.

\section{Results and discussions}

In this study synthesis and characterization of GAP polymers was performed. The synthesis of GAP was performed from epychlorohydrine using ED, BD and GLY initiator in the first step to obtain poly(epichlorohydrine) $\mathrm{PECH}$, and reaction of $\mathrm{PECH}$ with the $\mathrm{NaN}_{3}$ was performed at different temperatures and using solvents (dimethylformamide - DMF, dimethylsulfoxide - DMSO and dimethylacetamide (DMA)) following the reaction condition given in Table 1.

Table 1. Yield of the PECH and GAP prepolymers obtained at different experimental conditions

\begin{tabular}{|c|c|c|c|c|c|c|}
\hline \multirow{2}{*}{ Experiment } & \multirow{2}{*}{ Initiator } & \multirow{2}{*}{$\begin{array}{l}\text { PECH, } \\
\text { Yield, \% }\end{array}$} & \multirow{2}{*}{$\begin{array}{c}\text { PECH: } \\
\mathrm{NaN}_{3} \text { molar } \\
\text { ratio }\end{array}$} & \multicolumn{3}{|c|}{ GAP, yield $\%$} \\
\hline & & & & DMF & DMSO & DMA \\
\hline 1 & ED & 88 & $1: 1.05$ & 87 & 90 & 92 \\
\hline 2 & $\mathrm{BD}$ & 90 & $1: 1.05$ & 91 & 93 & 94 \\
\hline 3 & GLY & 91 & $1: 1.05$ & 92 & 91 & 90 \\
\hline
\end{tabular}

Obtained results indicate that low influences of solvent properties on syntheses of GAP energetic prepolymer. Generally, the effectiveness of nucleophilic substitution reaction $\left(\mathrm{SN}_{2}\right)$ could be dependent on solvent properties, e.g. acceleration of substitution reaction (push effect) due to solvent polarity. Solvent dipolarity/polarity, considering aprotic solvents DMF, DMSO and DMA, did not affect significantly yields of GAP products which means that selection of the solvent is not a main criteria yet their prices, if potential industrial application is considered, could be of a higher significance.

\section{Characterization of obtained materials with FTIR and NMR techniques}

\section{Spectral analysis - IR spectra}

The formation of glycidyl azide polymers were confirmed from the characteristic peaks obtained in FTIR spectra given in Figures 5 and 6 for PECH and GAP, respectively. 


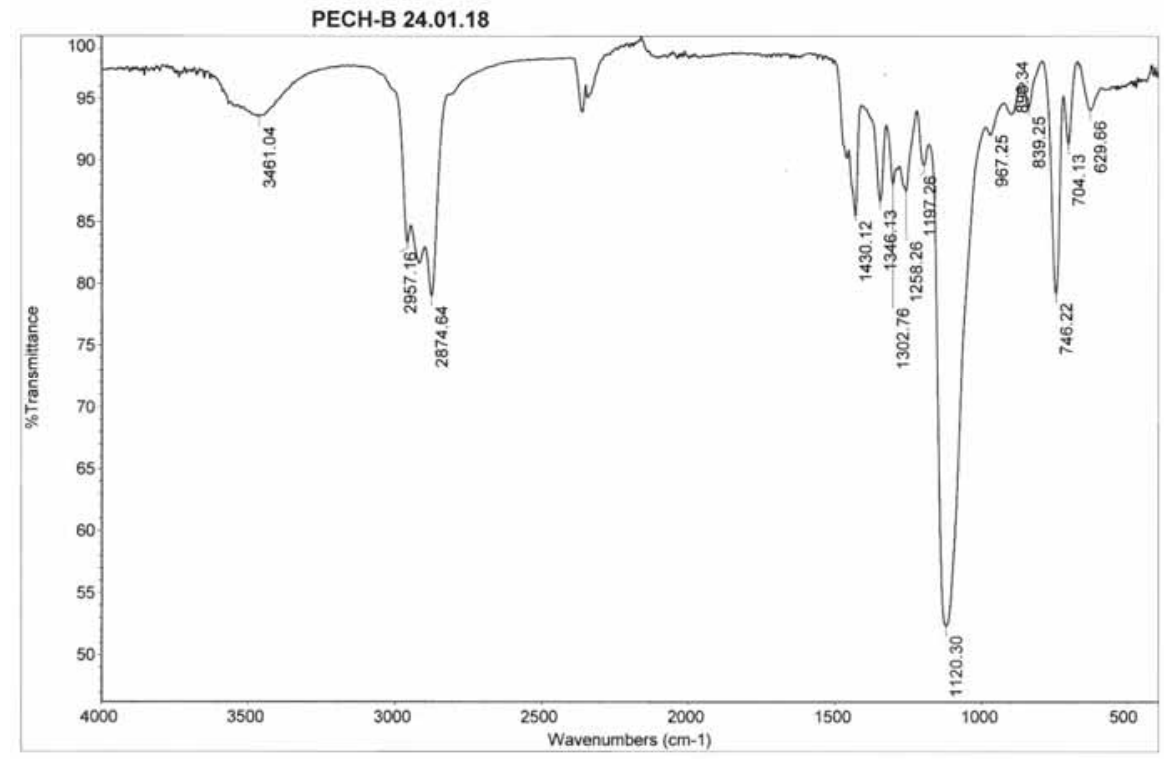

Figure 5. IR spectrum of PECH based on BD initiator

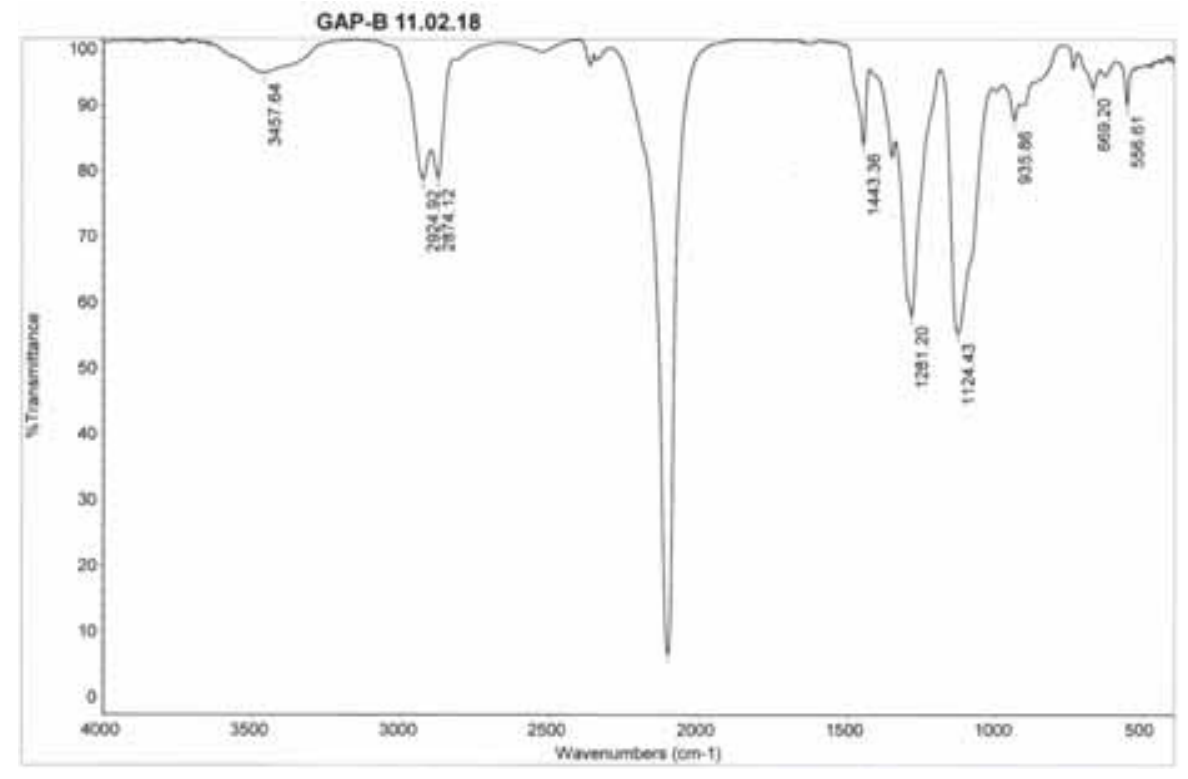

Figure 6. IR spectrum of GAP based on BD initiator

The FTIR spectrum of PECH shows bend at about 3461 $\mathrm{cm}^{-1}$ which is attributed to $\mathrm{OH}$ group stretching vibrations. The peaks at $2957 \mathrm{~cm}^{-1}$ and $2874 \mathrm{~cm}^{-1}$ originate from C-H symmetrical and asymmetrical stretching vibrations of the methylene group $\left(-\mathrm{CH}_{2}\right)$ observed for both PECH and GAP prepolymers. Corresponding bending vibrations are observed at about $1443 \mathrm{~cm}^{-1}$. Strong vibration band at $1120 \mathrm{~cm}^{-1}$ corresponds to $\mathrm{C}-\mathrm{O}-\mathrm{C}$ stretching vibrations in $\mathrm{PECH}$. The FTIR spectra show the main characteristic peaks at 1281 and $2100 \mathrm{~cm}^{-1}$, corresponds to presence of the azide group in the GAP polymer chain. Disappearance of the $\mathrm{CH}_{2} \mathrm{Cl}$ peak at 746 $\mathrm{cm}^{-1}$, observed in starting $\mathrm{PECH}$, indicates replacement of chlorine groups by azide units, and confirms successfulness of the azidation reactions. Similar results were obtained for both PECH and GAP based on ED and GLY initiators.

\section{${ }^{1} H$ NMR spectra of PECH and GAP}

For the structural analysis and comparative purpose the ${ }^{1} \mathrm{H}$ NMR spectra of PECH and GAP products were recorded and given in Figures 7 and 8 . The representative ${ }^{1} \mathrm{H}$ NMR spectra of PECH polymer (intermediate for GAP polymer synthesis), and assignment of the peaks are given in Fig.7. It is found that there is a group of multiple peaks at 3.3-3.9 ppm, which can be ascribed to hardly distinguishable the protons from methanediyl and methanetriyl groups present in $\mathrm{PECH}$. The characteristics resonance of analyzed materials, assigned according to prediction obtained using Mestre Nowa software, are as follow: $1.57 \mathrm{ppm}\left(-\mathrm{O}-\mathrm{CH}_{2}-\mathrm{CH}_{2}-\mathrm{CH}_{2}-\mathrm{CH}_{2}-\mathrm{O}\right.$; BD moiety), $3.32 \mathrm{ppm}\left(\mathrm{CH}_{2}-\mathrm{Cl}\right), 3.46$ and $3.49 \mathrm{ppm}\left(-\mathrm{CH}_{2}-\mathrm{O}\right)$, $3.63 \mathrm{ppm}\left(-\mathrm{CH}_{2}-\mathrm{O}, \mathrm{BD}\right.$ moiety), $3.81 \mathrm{ppm}\left(\mathrm{CH}-\mathrm{CH}_{2}-\mathrm{Cl}\right)$ and $5.20\left(\mathrm{CH}_{2}-\mathrm{OH}\right)$ groups. The other two chemical shifts of 2.51 are clearly attributed to solvent (DMSO), while the peaks at 2.76 and 2.89 appears from non-reacted ECH moiety [20].

The representative ${ }^{1} \mathrm{H}$ NMR spectra of GAP polymer based on $\mathrm{BD}$ initiator, and assignment of the peaks are given in Fig.8. It was found a group of multiple peaks at 3.3-3.9 ppm, which can be ascribed to the protons of $\mathrm{CH}_{2}$ and $\mathrm{CH}$ groups present in $\mathrm{PECH}$ which are difficult to separate. The characteristics resonance of analyzed materials, according to prediction, are as follow: $1.55 \mathrm{ppm}\left(-\mathrm{O}-\mathrm{CH}_{2}-\mathrm{CH}_{2}-\mathrm{CH}_{2}-\mathrm{CH}_{2}-\right.$ $\mathrm{O}$; BD moiety), $3.32 \mathrm{ppm}\left(\mathrm{CH}_{2}-\mathrm{N}_{3}\right)$, region from 3.50 to 3.80 ppm $\left(-\mathrm{CH}_{2}-\mathrm{O},\left(-\mathrm{CH}_{2}-\mathrm{O}, \mathrm{BD}\right.\right.$ moiety and $\left.\mathrm{CH}-\mathrm{CH}_{2}-\mathrm{N}_{3}\right)$ and $5.20\left(\mathrm{CH}_{2}-\mathrm{OH}\right)$ groups. The chemical shift at 2.50 is attributed to solvent (DMSO) [20]. 




Figure 7. ${ }^{1} \mathrm{H} \mathrm{NMR}$ spectra of $\mathrm{PECH}$ with $\mathrm{BD}$ initiator



Figure 8. ${ }^{1} \mathrm{H}$ NMR spectra of GAP with BD initiator

\section{Determination molecular weight of polymer}

The molecular weight of a polymer represents an average of the distribution of its various constituent molecules with different chain lengths. It is an important variable as it relates directly to the physical properties of the polymer. The area of a ${ }^{1} \mathrm{H}$ NMR peak is proportional to the molar concentration of the species resonating at the given chemical shift value, the area or intensity of the proton signal of given species is proportional to the amount of that species present in a given sample. Since the number-average molecular weight of a polymer $\left(M_{n}\right)$ is a summation of the product of the mole fraction of each species and its molecular weight, and is dependent on the total number of polymer particles in its dilute solution regardless of polymer size (weight), ${ }^{1} \mathrm{H} \mathrm{NMR}$ spectroscopy can be used to determine $M_{n}$ [23].

The determination of the block polymer's DP was done in two parts: the number of repeating units (n) in the GAP chain was based on determination of the peak areas of $\mathrm{CH}_{2}$ groups in $\mathrm{BD}$ unit $\left(\delta\right.$ 1.6) and the peak area corresponding to $\mathrm{CH}_{2}$ group in polymeric chain $(\delta 3.65)$ were obtained from the ${ }^{1} \mathrm{H}$ NMR spectrum. Having obtained n, the Mn of PECH and GAP were estimated by the summation of the atomic masses of the constituent atoms thus giving 2400 and $2112 \mathrm{~g} / \mathrm{mol}$, respectively.

Similar results were found for of PECH and GAP polymers with ethanediol and representative ${ }^{1} \mathrm{H}$ NMR spectra are shown in Figures 9 and 10.

\section{With ethanediol (ED)}

The characteristics resonance of analyzed materials, assigned according to prediction obtained using Mestre Nowa software, are as follow: $3.32 \mathrm{ppm}\left(\mathrm{CH}_{2}-\mathrm{Cl}\right), 3.44-3.51 \mathrm{ppm}$ (- $\left.\mathrm{CH}_{2}-\mathrm{O}\right), 3.65$ ppm (- $\mathrm{CH}_{2}-\mathrm{O}, \mathrm{ECH}$ moiety), 3.81 ppm (Cㅍ$\left.\mathrm{CH}_{2}-\mathrm{Cl}\right)$ and $5.20\left(\mathrm{CH}_{2}-\mathrm{OH}\right)$ groups. 


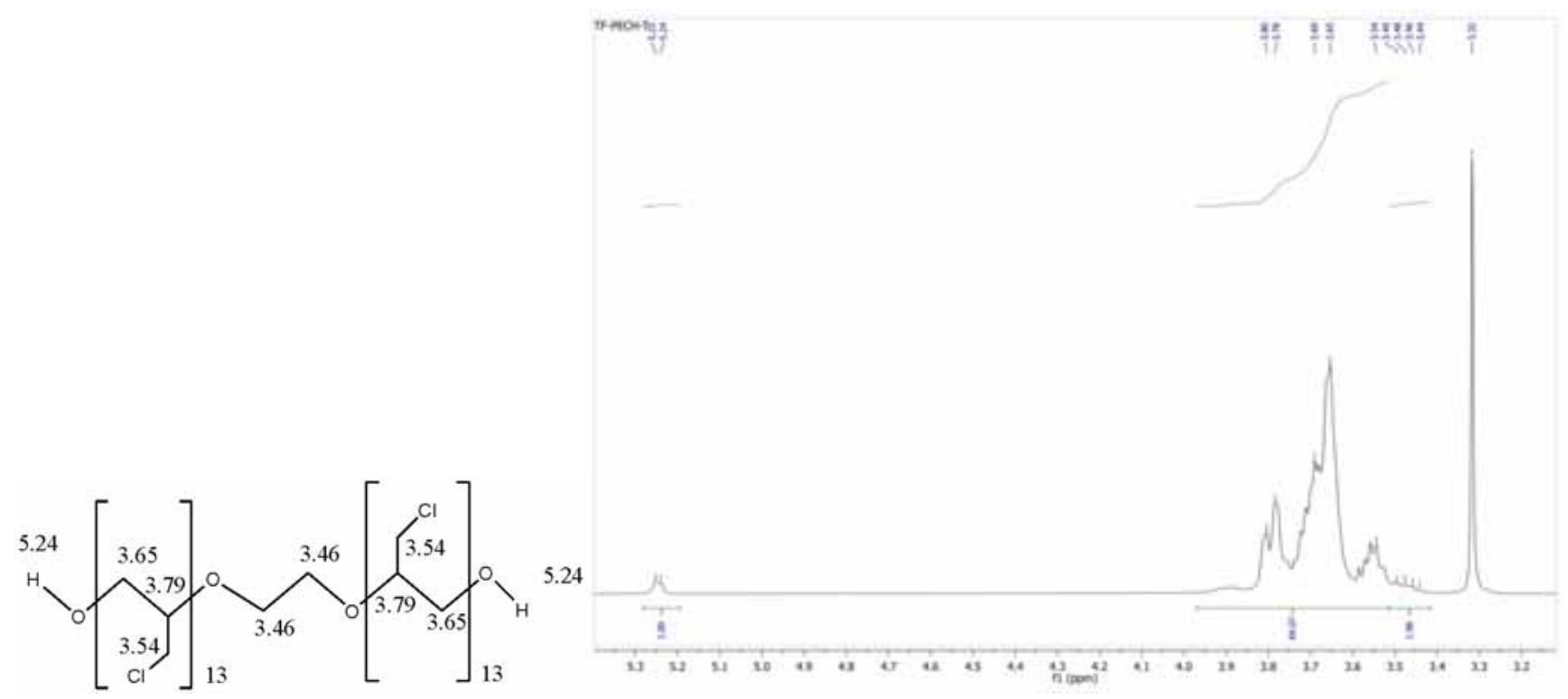

Figure 9. ${ }^{1} \mathrm{H}-\mathrm{NMR}$ of $\mathrm{PECH}$ with ethanediol

Calculated $M_{n}$ of synthesized PECH was found to be 2068 .

The representative ${ }^{1} \mathrm{H}$ NMR spectra of GAP polymer based on EG initiator, and assignment of the peaks are given in Fig.10. According to prediction, the characteristics resonance of analyzed materials are as follow: $3.32 \mathrm{ppm}\left(\mathrm{CH}_{2}-\mathrm{N}_{3}\right)$, region from 3.50 to $3.80 \mathrm{ppm}$ ( $-\mathrm{CH}_{2}-\mathrm{O}$ from $\mathrm{EG}$ moiety, $\mathrm{CH}-$ $\mathrm{CH}_{2}-\mathrm{N}_{3}$ and $\left.\mathrm{CH}-\mathrm{CH}_{2}-\mathrm{N}_{3}\right)$ and $5.20\left(\mathrm{CH}_{2}-\mathrm{OH}\right)$ groups.

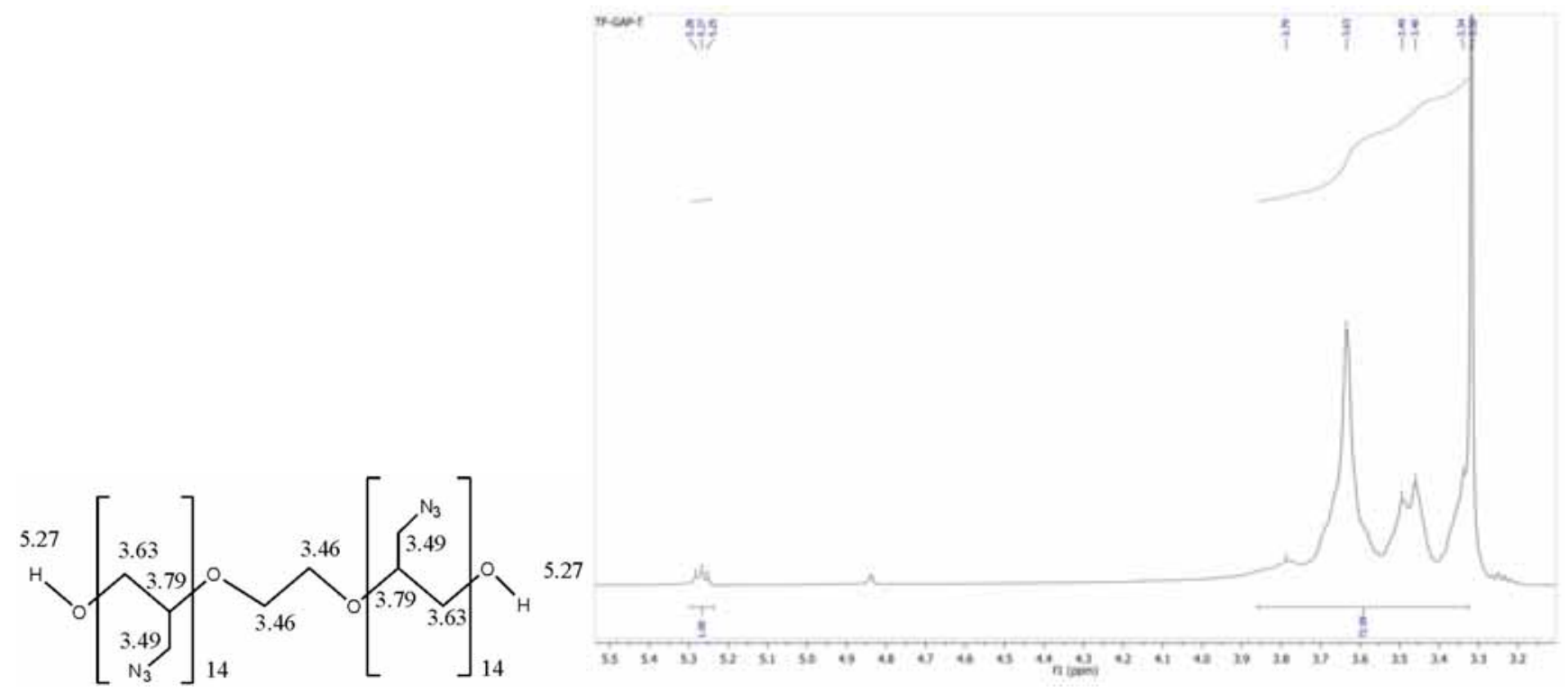

Figure 10. ${ }^{1} \mathrm{H}-\mathrm{NMR}$ of GAP with ethanediol

Calculated $M w$ of synthesized GAP based on ED was found to be 2220 .

Similar results of PECH and GAP prepolymers were obtained, and calculated $M w$ were found to be 2156 and 2224 , respectively.

\section{Differential scanning calorimetry (DSC) spectra}

The glass-rubber transition temperature of elastomer bonded energetic material is the most important property determining their in-service application [24]. Low glass transition temperature is preferred for the composite propellant binder, so that it can withstand a large spectrum of stress transients in an operation. This means that the $T_{\mathrm{g}}$ value of the composite propellant binder must be lower than the minimum service temperature (usually $-40^{\circ} \mathrm{C}$ to $-54^{\circ} \mathrm{C}$ depending on application) in order to avoid failure of the rocket motor during firing at low temperatures [25].

The glass transition temperature of PECH and GAP is an important parameter because a low binder $T \mathrm{~g}$ is beneficial for manufacturing of propellants. A high glass transition may lead to brittleness when the propellant is applied at low temperatures. The results of the DSC measurements are presented in Figures 11 and 12. 


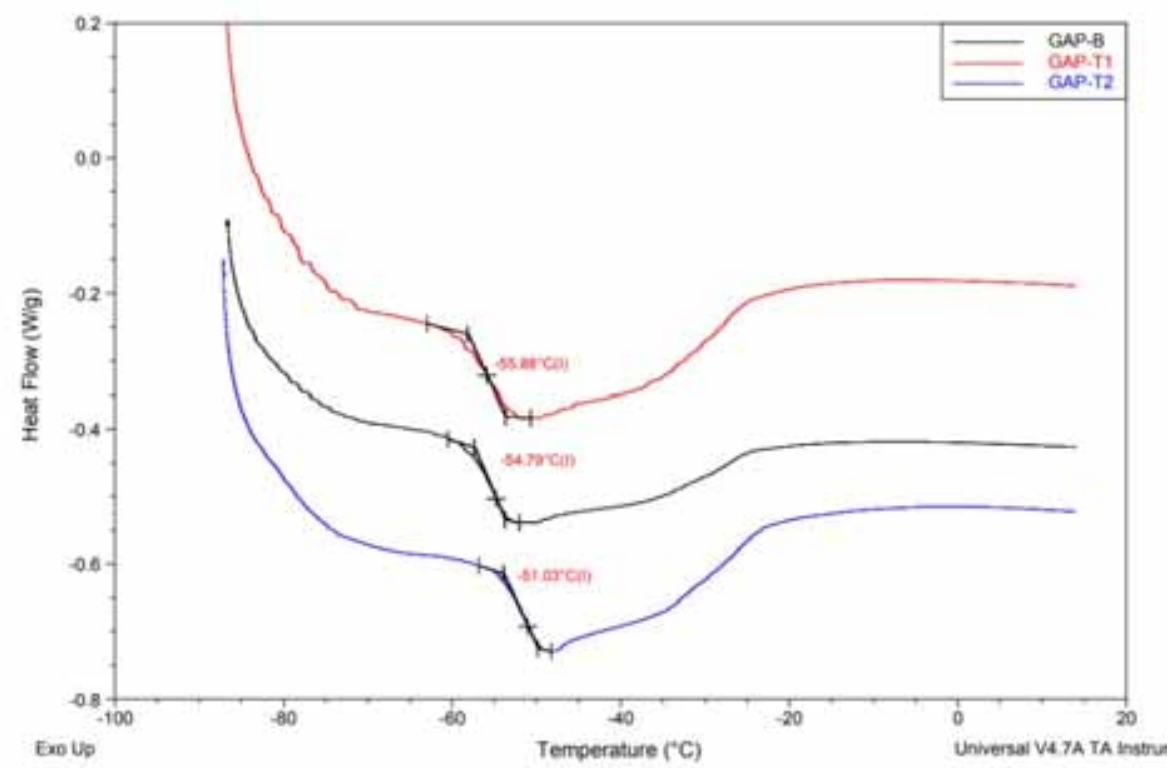

Figure 11. DSC spectra of GAPs



Figure 12. DSC spectra of PECHs

The $T_{\mathrm{g}}$ of tested different GAPs lays between $-51.0^{\circ} \mathrm{C}$ and $55.9^{\circ} \mathrm{C}$ (Table 2 ), which correspond to the reported value of $56.5^{\circ} \mathrm{C}[27]$.

GAP diols, both GAP based on either ED or BD, are a quite linear molecule, only the typical bond angles give some bends. This leads to lower free volume around the main chain compared to HTPB and raises the glass transition temperature. It has strong polar groups (C-O-C and $\mathrm{C}-\mathrm{N}-\mathrm{N}-\mathrm{N}$ ) and permanent dipolar interchain interactions, and has relatively short average molecular chain length [28]. High free volume provided by long chains of HTPB shifts the glass transition to lower temperatures (reported as $-83^{\circ} \mathrm{C}$ by Bhagawan et al.) [29].

Table 2. Glass transition temperature PECH and GAP prepolymers

\begin{tabular}{|c|c|c|c||}
\hline Sample & $T_{\mathrm{g}},\left[{ }^{\circ} \mathrm{C}\right]$ & Sample & $T_{\mathrm{g}},\left[{ }^{\circ} \mathrm{C}\right]$ \\
\hline \hline PECH BD & $-42,57$ & GAP BD & $-55,88$ \\
\hline PECH ED & $-41,91$ & GAP ED & $-54,79$ \\
\hline PECH GLY & $-35,31$ & GAP GLY & $-51,03$ \\
\hline
\end{tabular}

Three hydroxyl groups present in GAP GLY tested sample reduce the formation of free volume and therefore the main chain flexibility of GAP and reduce the glass transition temperature. Nevertheless the obtained values confirm that the tested GAP prepolymers could be used for binder in propellant and explosives formulations.

Viscosimetry, density and $\mathrm{OH}$ - equivalent weight of polymer

The average molecular weights of PECH samples were determined by combining ${ }^{1} \mathrm{H}$ NMR and viscosimetry techniques, based on the hydrodynamic volume concept. An Ubbelohde viscosimeter was used and PECH concentrations were varied between 0,5 and $5 \mathrm{~g} / \mathrm{L}$. The molecular weights were calculated using eq. (1) where $[\eta]$ represents the intrinsic viscosity of the specific polymer-solvent system, and $M_{n}$ the weight-average molecular weight of PECH [19]:

$$
[\eta]=8,93 \times 10^{-5} M_{n}^{0,731}
$$

Density determination was peformed by pycknometer method. When the solid is placed in a pycknometer filled with a liquid of known density, the volume of the liquid which will overflow is equal to the volume of the solid. The mass of the liquid which will overflow is determined as the difference between the sum of the mass of the pycknometer filled with liquid plus the mass of the solid and the mass of the 
pycknometer filled with liquid after the solid has been placed inside. The volume occupied by this mass is determined from the known density of the liquid. It is necessary that the solid is insoluble in the liquid used. The density of the solid is determined from these measurements of mass and volume. Density is defined as the ratio of the mass of a body to its volume [30]. Its experimental determination requires the measurement of these two quantities for the selected piece of material. Results of viscosimetry and density measurement of different PECHs prepolymer are shown in Table 3.

Table. 3. Molecular weight of PECH prepolymers

\begin{tabular}{|c|c|c|c|c|c||}
\hline Method & HV & AV & $\begin{array}{c}\text { Mn [g/mol] } \\
{ }^{1} \text { H NMR }\end{array}$ & $\begin{array}{c}\text { Mn [g/mol] } \\
\text { viscosimetry }\end{array}$ & $\begin{array}{c}\text { Density } \\
{\left[\mathrm{g} \cdot \mathrm{cm}^{-3}\right]}\end{array}$ \\
\hline \hline PECH (GLY) & 138 & 7 & 2186 & 2238 & 1.29 \\
\hline PECH (ED) & 67 & 9 & 2068 & 2112 & 1.31 \\
\hline PECH (BD) & 60 & 6 & 2400 & 2220 & 1.28 \\
\hline
\end{tabular}

Also, the average molecular weights of GAP samples were determined by using both ${ }^{1} \mathrm{H}$ NMR and viscosimetry techniques, based on the hydrodynamic volume concept. The Mark-Houwink relations for polystyrene (PS) in THF and for GAP are:

$$
\begin{gathered}
{[\eta]_{\mathrm{PS}}=9.1 \times 10^{-5} M_{\mathrm{n}}^{0.746}} \\
{[\eta]_{\mathrm{GAP}}=2.8 \times 10^{-4} M_{\mathrm{n}}^{0.62}}
\end{gathered}
$$

For a given elution volume, both PS and GAP have the same hydrodynamic volume $[\eta] M_{\mathrm{n}}$, by combining the MarkHouwink eqs. (2) and (3) the following relations were obtained:

$$
M_{\mathrm{GAP}}=0.51 M_{\mathrm{PS}}^{1.075}
$$

Therefore, by using these eq. (4) the PS calibration curve could be transposed to give the calibration curves for GAP, from which the $M_{\mathrm{n}}$ averages of the GAP samples could be calculated. The obtained results together with density determination are given in Table 4.

Table 4. Molecular weight of GAP prepolymers

\begin{tabular}{|c|c|c|c|c|c||}
\hline Method & HV & AV & $\begin{array}{c}M_{\mathrm{n}}[\mathrm{g} / \mathrm{mol}], \\
{ }^{1} \mathrm{H} \text { NMR }\end{array}$ & $\begin{array}{c}M_{\mathrm{n}}[\mathrm{g} / \mathrm{mol}], \\
\text { viscosimetry }\end{array}$ & $\begin{array}{c}\text { Density } \\
{\left[\mathrm{g} \cdot \mathrm{cm}^{-3}\right]}\end{array}$ \\
\hline \hline GAP (GLY) & 132 & 5 & - & 2126 & 1.28 \\
\hline GAP (ED) & 62 & 6 & 2400 & 2056 & 1.27 \\
\hline GAP (BD) & 58 & 4 & 2224 & 1987 & 1.29 \\
\hline
\end{tabular}

The $M_{\mathrm{n}}$ values obtained from the viscosimetry were lower than the theoretical molecular weights obtained by NMR analysis. The viscosimetry underestimated the polymer's $M_{\mathrm{n}}$ because the constituent polymer usually have different extent of interaction with solvent, degree of coiling which affect hydrodynamic volume and thus value of $M_{\mathrm{n}}$ determined.

\section{Sensitivity to thermal stimuli}

Practical determination of sensitivity to thermal stimuli used to determine ignition temperature and induction period. Ignition temperature is the temperature at which a small sample of the energetic materials placed in a test tube and externally heated at a constant rate of temperature increase until ignites. Induction period is the time needed for the ignition of the sample at a given constant temperature. For safe handling with the polymers, the sensitivity to thermal stimuli was measured. Tests are in accordance with STANAG 4491 (Ed.1) and SORS 8457/96 [31-32]. Table 5 shows the determined values of ignition temperature and induction period for different GAPs.
Table 5. Ignition temperature and induction period of GAP prepolymers

\begin{tabular}{|c|c|c|c|c||}
\hline \multirow{2}{*}{ Sample } & \multirow{2}{*}{$\begin{array}{c}\text { Ignition temperature, } \\
\mathrm{T}\left[{ }^{\circ} \mathrm{C}\right]\end{array}$} & \multicolumn{3}{|c|}{ Induction period, $\tau[\mathrm{s}]$} \\
\cline { 3 - 5 } & & $230^{\circ} \mathrm{C}$ & $240^{\circ} \mathrm{C}$ & $250^{\circ} \mathrm{C}$ \\
\hline \hline GAP BD & 239 & 123 & 101 & 79 \\
\hline GAP ED & 237 & 220 & 132 & 107 \\
\hline GAP GLY & 232 & 150 & 113 & 78 \\
\hline
\end{tabular}

The results obtained using the sensitivity method to thermal stimuli show that samples, heated till ignition, showed fast burn occurred and also another visible/audible response: intense sound, low flash and a little light-colored smoke. After tests little yellow-brown residue remain in the tube with concomitant glass shot at about $20 \%$ of the test tube.

\section{Conclusion}

The glycidyl azide polymers successfully synthesized via conventional two-step process involving the bulk cationic polymerization of $\mathrm{ECH}$, in the presence of ethanediol, butanediol and glycerol as an initiator and BTFE as a catalyst. The synthesized GAP prepolymers were characterized by FTIR and ${ }^{1} \mathrm{H}-\mathrm{NMR}$ spectroscopy. Thermal characteristics of GAP polymer are determined by DSC. Physico-chemical and rheological performances were determined, end groups analysis and molecular mass measurement, using both NMR technique and viscosimetry method, were performed.

The synthesized polymers, glycidyl azide polymer (GAP), is an energetic, thermally stable, insensitive a hydroxyterminated aliphatic polyether containing alkyl azide groups which could be used as an energetic binder in advanced energetic materials. This new energetic material (for Serbia), GAP, is a good candidate for new potential applications, such as: low-smoke solid rocket propellants, composite explosives, gun propellants and pyrotechnics, in order to enhance the performance and stability, reduce the vulnerability and improve the physicochemical properties of energetic formulations. Further investigations with respect to the use of synthesized GAP in energetic materials are subject of current work, and will be presented in a separate paper.

\section{Acknowledgment}

The authors would like to thank to Mirjana Dimić for DSC measurements, Vladimir Mladenović for the sensitivity to thermal stimuli tests and Aleksandra Božić for NMR spectroscopic measurements. The authors would also like to thank to staff of the Organic Chemistry Department on the Faculty of Technology and Metallurgy for their support in the laboratory.

\section{References}

[1] CERRI,S., BOHN,M.A., MENKE,K., GALFETTI,L.: Ageing Behaviour of HTPB Based Rocket Propellant Formulations, Central European Journal of Energetic Materials, 2009, Vol.6, No.2, pp.149-165.

[2] RODIĆ,V., DIMIĆ,M., BRZIĆ,S., GLIGORIJEVIĆ,N.: Cast Composite Solid Propellants with Different Combustion Stabilizers, Scientific Technical Review, ISSN 1820-0206, 2015, Vol.65, No.2, pp.3-10.

[3] BRZIĆ,S., UŠĆUMLIĆ,G., MILOJKOVIĆ,A., RODIĆ,V., BOGOSAVLJEVIĆ,M.: Viscoelastic Properties of Carboxyl-Terminated (Butadiene-co-Acrylonitrile)-Based Composite Rocket Propellant Containing Tris(2,3-Epoxypropyl) Isocyanurate as Bonding Agent, Scientific Technical Review, ISSN 1820-0206, 2015, Vol.65, No.4, pp.28-36.

[4] AGRAWAL,J.P., HODGSON,R.: Organic Chemistry of Explosives, John Wiley \& Sons Ltd, Chichester, 2007, ISBN-13 978-0-470-02967-1.

[5] MEYER,R., KÖHLER,J., HOMBURG,A.: Explosives, Wiley-VCH, Verlag, GmbH \& Co. KG, Sixth Completely Revised Edition, 2007. ISBN 978-3-527-31656-4. 
[6] KUBOTA,N.: Propellants and Explosives, Thermochemical Aspects of Combustion, Wiley-VCH Verlag GmbH \& Co. KG, Weinheim, Germany, Second Edition, 2007, ISBN 978-3-527-31424-9.

[7] AGRAWAL,J.P.: High Energy Materials, Propellants Explosives and Pyrotechnics, Wiley-VCH Verlag GmbH \& Co. KG, Weinheim, Germany, 2010, ISBN 978-3-527-32610-5.

[8] URBANSKI,T.: Chemistry and Technology of Explosives, Vol. 2, Pergamon Press, Oxford, 1964

[9] BETZLER,M.F., HARTDEGEN,A.V., KLAPOTKE,M.T., SPROLL,M.S.: A New Energetic Binder: Glycidyl Nitramine Polymer, Central European Journal of Energetic Materials, 2016, Vol.13, No.2, pp.289-300.

[10] HAFNER,S., KEICHER,T., KLAPOTKE,M.T.: Copolymers based on GAP and 1,2-Epoxyhexane as Promising Prepolymers for Energetic Binder Systems, Propellants Explosives Pyrotechnics, 2018, Vol.43, pp.126-135.

[11] GAYATHRI, S., RESHMI, S.: Nitrato Functionalized Polymers for High Energy Propellants and Explosives: Recent Advances, Polymer advanced technologies, 2017, Vol.23, pp.112-123.

[12] NAZARE,A.N., ASTHANA,S.N., SINGH,H.: Glycidyl azide polymer (GAP) - an energetic component of advanced solid rocket propellants a review, Journal of Energetic Materials, 1992, Vol.10, pp. 043-063.

[13] FRANKEL,M.B., GRANT,L.R., FLANAGAN,J.E.: Historical Development of Glycidyl Azide Polymer, Journal of Propulsion and Power, May - June 1992, Vol.8, No.3, pp.550-563.

[14] AHAD,E.: Proces for the preparation of alkyl azide-substituted hydroxy-terminated polyethers, EUROPEAN patent 0274 213, 1987 11-27.

[15] AHAD,E., Branched hydroxy-terminated aliphatic polyethers, EUROPEAN patent 0350 226, 1990-01-10.

[16] PROVATAS,A.: Energetic Polymers and Plasticisers for explosive formulations - a review of recent advances, Technical Report 0966, DSTO, 1-32, 2000.

[17] VANDENBERG,J.E., WOODS,F.: Polyethers containing azidomethyl side chains, US patent 3,645,917, 1972-02-29.

[18] AGAWANE,N.T., SOMAN,R.R., WAGH,R.M., ATHAR,J., TALAWAR,M.: Optimization of Curing Agents for Linear Difunctional Glycidyl Azide Polymer (GAP), with and without Isocyanate, for Binder Applications, Central European Journal of Energetic Materials, 2018, Vol.15, No.1, pp.206-222.

[19] BROCHU,S., AMPLEMAN,G.: Synthesis and Characterization of Glycidyl Azide Polymers Using Isotactic and Chiral Poly(epichlorohydrin)s, Macromolecules, July 1996, Vol.29, No.17, pp.5539-5545.

[20] MOHAN,Y.M., RAJU,M.P., RAJU,K.M.: Synthesis, spectral and DSC analysis of glycidyl azide polymers containing different initiating diol units, Journal of Applied Polymer Science, March 2004, Vol.93, pp.2157-2163.

[21] CAPPELLO,M., FILIPI,S., MORI,L., POLACCO,G.: Glycidyl Azidebutadiene Block Copolymers: 2 Synthesis from Mesylated Precusor, Propellants Explosives Pyrotechnics, 2017, Vol.42, pp. 974-981.

[22] MOHAN,Y.M., MANI,Y., RAJU,K.M.: Synthesis of azido polymers as potential energetic propellant binders - review, Designed Monomers and Polymers, 2006, Vol.9, No.3, pp.201-236.

[23] IZUNOBI,J.U., HIGGINBOTHAM,C.L.: Polymer Molecular Weight Analysis by ${ }^{1} H$ NMR Spectroscopy, Journal of Chemical Education, 2011, Vol.88, pp.1098-1104.

[24] BOHN,M.A.: Impacts on the Loss Factor Curve and Quantification of Molecular Rearrangement Regions from it in Elastomer Bonded Energetic Formulations, Energetics Science \& Technology in Central Europe, ed. R. Armstrong, J. Short, and D.K. Anand, University of Maryland: CALCE EPSC Press, 2012, pp. 195-235.

[25] BOHN,M.A., AMSTRONG,J.R., SHORT,R.J., ANAND,D.K.: Impacts on the Loss Factor Curve and Quantification of Molecular Rearrangement Regions from it in Elastomer Bonded Energetic Formulations, CALCE EPSC Press, University of Maryland, 2012, pp.195-235.

[26] WINGBORG,N.: Increasing the tensile strength of HTPB with different isocyanates and chain extenders, Polymer Testing, 2002, 21, pp. 283-287.

[27] SEYIDOGLU,T., BOHN,M.A.: Effect of curing agents and plasticizers on the loss factor curves of HTPB-binders quantified by modelling, in Proceedings of the $18^{\text {th }}$ International Seminar on New Trends in Research of Energetic Materials, Pardubice, Czech Republic, 2015, pp.794-815.

[28] BOHN,M.A., CERRI,S.: Molecular mobility in binder systems, Proceedings of the $42^{\text {nd }}$ International Annual Conference of ICT, Karlsruhe, Germany, June 28 to July 1, 2011, pp.96-1 to 96-33.

[29] BHAGAWAN,S.S., PRABHAKARAN,N., RAMA,R.M., NINAN,N.K.: Viscoelastic behaviour of solid propellants based on various polymeric binders, Defence Science Journal, 2011, Vol.45, pp.17-23.

[30] SORS 1472/83, POLIOLI, Beograd, 1983.

[31] STANAG 4491, Explosives, Thermal sensitiveness and explosiveness tests, NATO Standardization Agency (NSA), promulgated on 28 August 2002.

[32] SORS 8457/96, Metode kontrolisanja kvaliteta brizantnih eksploziva, Beograd, 1996.

\title{
Sinteza i karakterizacija glicidil azid polimera atraktivnog veziva za energetske materijale
}

\begin{abstract}
Glicidil azid polimer (GAP), energetski, termički stabilni, nisko osetljivi, hidroksi terminirani polimer, sintetisan je korišćenjem različitih diola i triola kao inicijatora. GAP je pripremljen azidacijom poli(epihlorohidrina) (PECH) sa različitim


katalizatorom i poliolom kao ko-katalizatorom. Sintetisani polimeri su okarakterisani pomoću IR-spektroskopije, priroda hidroksi terminirane grupe je potvrdena protonskom NMR spektroskopijom. Određene su temperature staklastog prelaza $\left(T_{g}\right)$ i osetljivosti na termičke impulse. Fizičko-hemijske i reološke osobine su potvrđene određivanjem: hidroksilnog broja, molarne mase, gustine i viskoznosti.
\end{abstract}

Ključne reči : polimeri, polimerno vezivo, glicidal azidni polimer, energetski polimeri, hemijska sinteza, osobine materijala, fizičko-hemijske osobine.

\section{Синтез и характеристики глицидного азидного полимера привлекательного связующего для энергетических материалов}

\footnotetext{
Глицидилазидный полимер (ГАП), энергетический, термически стабильный, малочувствительный полимер с концевыми гидроксильными группами, был синтезирован с использованием различных диолов и триолов в качестве инициаторов. ГАП получали азидированием поли(эпихлоргидрина) (ПЭРЛ) различными полиолами в цепи
} 
полимера. ПЭРЛ был получен катионной полимеризацией путём раскрытия кольца с ВF ${ }_{3}$-эфиратом в качестве катализатора и полиолом в качестве сокатализатора. Синтезированные полимеры были охарактеризованы с помощью ИК-спектроскопии, а природа гидроксильной группы подтверждена с помощью протонной ЯМРспектроскопии. Определены температуры стеклования $(T g)$ и чувствительности к тепловым импульсам. Физикохимические и реологические свойства были подтверждены путём определения: гидроксильного числа, молярной массы, плотности и вязкости.

Ключевые слова: полимеры, полимерное связующее, глицидный азидный полимер, энергетические полимеры, химический синтез, свойства материала, физико-химические свойства.

\title{
Synthèse et caractérisation de polymer glycidil azide liant attrayant pour les matériaux énergétiques
}

\begin{abstract}
Le glycydil azide polymer (GAP) énergétique, stable termique et peu sensible, polymer hydroxyle terminé a été synthétisé au moyen de différents diols et triols comme l'iniciateur. Le GAP a été préparé par l'azidiation de poly(épichlorohydrin) (PECH) avec les différents polyols dans la chaîne polymer. PECH a été obtenu par la polymerisation cationique de l'ouverture de l'anneau avec $\mathrm{BF}_{3}$ comme catalisateur et le polyol comme co-catalisateur. Les polymers synthétisés se caractérisent par la spectroscopie IR. La nature du groupe hydroxyle terminé a été confirmée par la spectrosopie protone NMR. On a déterminé les températures de la transition de verre de la température (Tg) et la sensitivité aux impulsions thermiques. Les performances physiques et chimiques ainsi que rhéologiques ont été confirmées par la détermination du nombre hydroxile, de la masse molare, de la densité et de la viscosité.
\end{abstract}

Mots clés: polymers, liant polymer, glycidyl azide polymer, polymers énergétiques, synthèse chimique, propriétés des matériaux, performances chimiques physiques. 